\title{
A Comparative Study of Students' Happiness Levels and Thinking Styles in Physical Education and Sport Teaching, and Other Departments, in Turkey
}

\author{
Emre Ozan Tingaz ${ }^{1}$, Muhsin Hazar $^{1}$, Hacer Özge Baydar ${ }^{1}$, Belgin Gökyürek ${ }^{1} \&$ Temel Çakıroğlu ${ }^{2}$ \\ ${ }^{1}$ Gazi University Sport Sciences Faculty, Ankara, Turkey \\ ${ }^{2}$ Hasan Doğan Physical Education and Sports, Karabük, Turkey \\ Correspondence: Emre Ozan Tingaz, Gazi University Sport Sciences Faculty, Ankara, Turkey
}

Received: May 4, 2018

doi:10.5430/ijhe.v7n3p163
Accepted: May 25, 2018

Online Published: June 10, 2018

URL: https://doi.org/10.5430/ijhe.v7n3p163

\begin{abstract}
The objectives of this research were to compare the happiness and thinking styles of undergraduate students in the Physical Education and Sports Teaching Department and different departments, and to examine the relations between the students' happiness levels and their thinking styles. Using the correlational study design 661, undergraduate students were determined by a convenience sampling method. Participants were selected in terms of being easily accessible from Gazi University, which is located in the Ankara province, Turkey. The analysis indicated that the Department of Physical Education and Sports Teaching students' average level of happiness was significantly higher than in some other departments. However, the Department of Physical Education and Sports Teaching students' need for cognition was not significantly different from the students from other departments. Physical Education and Sports Teaching students' faith in intuition was significantly higher than the Department of Guidance and Psychological Counseling students'. Besides, the happiness levels and thinking styles did not differ significantly by gender. There was a positive correlation between their faith in intuition and happiness. However, there was no significant relation between their happiness levels and need for cognition, nor need for cognition and their faith in intuition.
\end{abstract}

Keywords: the department of physical education and sports teaching, happiness, thinking styles, undergraduate students

\section{Introduction}

The concept of thinking style was introduced by Sternberg (1988) in his "Mental Self-Government Theory". "The basic idea of the theory of Mental Self-government is that the forms of government we have in the world are not coincidental. Rather, they are external reflections on what goes on in people's minds. They represent alternative ways of organizing our thinking. Thus, the forms of government we see are mirrors of our minds." (Sternberg, 1999, p. 19) "'Thinking styles' refer to the ways in which people choose to use or exploit their intelligence as well as their knowledge. Styles are not abilities, but rather how these abilities (and the knowledge acquired through them) are used in day-to-day interactions with the environment." (Grigorenko \& Sternberg, 1995) "Thinking styles concern how one prefers to think about the material as learning about it or after already it." (Zhang, 2002) Mankind has been running some thinking processes while exhibiting certain intellectual and behavioral reactions, both in interpersonal relationships and in dealing with life events (İmamoğlu, 2008).

Some variables may influence the development of thinking styles, such as gender, age, culture, personality types, leadership experience, travel experience, the number of hobbies, parenting styles, school education types and quality levels, and profession. Besides, socializing is thought to be more effective than the naturally preferred thinking styles based on genetic factors (Sternberg, 2009; Zhang, 2000, 2001). Socialization has also increased the happiness (Csikszentmihalyi \& Hunter, 2003). In addition, there is a significant relation between happiness and exercise (Farahani, Saiah, Heidary, Nabilu \& Eskandaripour, 2011). In this context, it is useful to define the concept of happiness, which is another dependent variable of the research. Jacobsen (2007) emphasized that distinguishments between brief and durable states of happiness are made using two distinct definitions. 
We understand_ordinary happiness or bliss to be a brief state of mind during which an individual feels that all essential needs have been fulfilled and that all essential goals have been reached. The individual feels fulfilled, and in some cases even merged with the surroundings or nature. By real or genuine happiness, we understand a durable state of balance between the individual's wishes, goals, and needs on the one hand, and the surroundings or the world on the other. This state is associated with well-being, serenity and relaxation.

Happiness, which is the study area of positive psychology, is related to well-being (Ansari \& Parveen, 2016; Carr, 2011, p. 2). "Happiness is a mental or emotional state of well-being characterized by positive or pleasant emotions ranging from contentment to intense joy." (Sundriyal \& Kumar, 2014) It can be considered that socializing influences both happiness and thinking styles. Besides, it is known that exercise has an important role for the socialization process (Kaplan \& Çetinkaya, 2014; Orphan, 2010). In this context, the aim of this study is to compare the happiness levels and thinking styles of the Physical education and Sport Teaching department students to students of other departments and examine the relation between happiness and thinking styles.

The research questions of this study are as follows:

1. Is Physical Education and Sport Teaching students' happiness level different from that of the students in other departments?

2. Are Physical Education and Sport Teaching students' thinking styles different from that of the students in other departments?

3. Are happiness and thinking styles differentiated by gender and age in university students?

4. Is there a relation between thinking styles and happiness?

\section{Method}

\subsection{Research Model}

In this study, we were try to compare the thinking styles and happiness level of undergraduate students of the Physical Education and Sport Teaching to different departments and investigate the relation between happiness and thinking styles. We used a correlational study design to this end. Because, correlational study involves measuring two or more variables and determining the correlation between them (Heppner, Wampold \& Kivlighan, 2007; Rovai, Baker \& Ponton, 2013; Schneider, Gruman \& Coutts, 2011).

\subsection{Participants}

Through a convenience sampling method, 661 undergraduate students were determined. "Convenience sampling entails using the most conveniently available people as participants." (Pilot \& Back, 2010, p. 309) The students were selected both in terms of being easily accessible from the Gazi University, which is located in the Ankara province, Turkey. The participants involved 403 women and 258 men total who had a mean age of 21.01; they were from the Department of Physical Education and Sports Teaching (81 participants), the Department of Art Education (53 participants), the Department of Early Childhood Education (72 participants), the Department of School Teaching (74 participants), the Department of Guidance and Psychological Counseling (60 participants), the Department of History (60 participants), the Department of Turkish Language and Literature (52 participants), the Polatl Social Sciences Vocational School (the Department of Child Care and Youth Services, the Department of Hair and Beauty Services, and the Department of Textile Clothing Footwear and Leather) (71 participants), the Department of Electrical and Electronic Engineering (71 participants), and the Faculty of Tourism (Tourism Management-Recreation Management) (67 participants).

\subsection{Research Instruments}

In the context of the present study, the data was collected with the "Oxford Happiness Scale" and the "Rational-Experienced Thinking Styles Scale" from the participants.

The Oxford Happiness Scale was originally developed by Hills and Argyle (2002), and the validity and reliability of the Turkish form was adapted by Dogan and Sapmaz (2012). The scale consists of 28 items and is a one-dimensional structure.

The Rational-Experiential Thinking Style scale was first developed by Epstein, Pacini, Denes-Raj, and Heier (1996). The validity and reliability of the Turkish version was adapted by Bulus (2003). It consists of 19 items and two sub-dimensions. The "Need for Cognition" of the scale is defined as the sub-scale analytical-rational thinking style, while the "Faith in Intuition" subscale is defined as the intuitive-experiential thinking style. 


\subsection{Data Analysis}

The data was analyzed through the SPSS 23.00 statistical software. Then the normality analysis of the data was done using the Kolmogorov-Smirnov Test. An analysis of the data obtained from the research showed that it did not meet the normal distribution. Because of this reason, non-parametric tests were used. The Kruskal Wallis test was used for comparing the departments and age groups according to the Happiness and Rational-Experiential Thinking Styles subscales. The Mann Whitney $U$ test was used for comparing gender according to the Happiness and Rational-Experiential Thinking Styles subscales. In addition, the Spearman Correlation Analysis was used to investigate the relation between the Happiness and Rational-Experiential Thinking Styles.

\section{Results}

Table 1. Comparison of Happiness Levels According to Departments

\begin{tabular}{|c|c|c|c|c|c|c|c|}
\hline & & \multicolumn{6}{|c|}{ Happiness } \\
\hline & & Mean & $\begin{array}{l}\text { Std. } \\
\text { Dev. }\end{array}$ & Median & Min & Max & $\mathrm{p}$ \\
\hline \multirow{9}{*}{$\begin{array}{l}\text { Department of } \\
\text { Physical Education } \\
\text { and Sports } \\
\text { Teaching } \\
\text { Mean=3.69 } \\
\text { Std. Deviation= } \\
\text { Median=3.69 } \\
\text { Minimum=2.41 } \\
\text { Maximum=4.55 }\end{array}$} & Department of Art Education & 3.48 & 0.49 & 3.45 & 2.55 & 4.48 & 0.415 \\
\hline & $\begin{array}{l}\text { Department of Early Childhood } \\
\text { Education }\end{array}$ & 3.61 & 0.59 & 3.48 & 2.45 & 4.55 & 1.000 \\
\hline & Department of School Teaching & 3.67 & 0.48 & 3.69 & 2.41 & 4.55 & 1.000 \\
\hline & $\begin{array}{l}\text { Department of Guidance and } \\
\text { Psychological Counseling }\end{array}$ & 3.35 & 0.44 & 3.34 & $2 \mathrm{i} 59$ & 4.28 & $0.001 *$ \\
\hline & Department of History & 3.50 & 0.44 & 3.50 & 2.21 & 4.31 & 1.000 \\
\hline & $\begin{array}{l}\text { Department of Turkish Language } \\
\text { and Literature }\end{array}$ & 3.35 & 0.52 & 3.38 & 2.21 & 4.34 & $0.020 *$ \\
\hline & $\begin{array}{l}\text { Department of Electrical and } \\
\text { Electronic Engineering }\end{array}$ & 3.58 & 0.60 & 3.55 & 2.34 & 4.55 & 1.000 \\
\hline & Faculty of Tourism & 3.67 & 0.54 & 3.59 & 2.41 & 4.55 & 1.000 \\
\hline & $\begin{array}{l}\text { Polatl Social Sciences Vocational } \\
\text { School }\end{array}$ & 3.43 & 0.53 & 3.41 & 1.69 & 4.48 & $0.035^{*}$ \\
\hline
\end{tabular}

$* \mathrm{p}<0.05$

According to the Kruskal Wallis test results, the Department of Physical Education and Sports Teaching students' happiness level average was significantly different from the Department of Guidance and Psychological Counseling, Turkish Language and Literature Department, and the Polatlı Social Sciences Vocational School $(\mathrm{p}<0.05)$. 
Table 2. A Comparison of Need for cognitions According to the Departments

\begin{tabular}{|c|c|c|c|c|c|c|c|}
\hline & & \multicolumn{6}{|c|}{ Need for cognitions } \\
\hline & & Mean & $\begin{array}{l}\text { Std. } \\
\text { Dev. }\end{array}$ & Median & Min & Max & $\mathrm{p}$ \\
\hline \multirow{9}{*}{$\begin{array}{l}\text { Department of } \\
\text { Physical Education } \\
\text { and Sports } \\
\text { Teaching } \\
\text { Mean=3.23 } \\
\text { Std. Dev. }=0.48 \\
\text { Median=3.24 } \\
\text { Minimum=2.41 } \\
\text { Maximum=4.24 }\end{array}$} & Department of Art Education & 3.49 & 0.51 & 3.47 & 2.18 & 4.53 & 0.094 \\
\hline & $\begin{array}{l}\text { Department of Early Childhood } \\
\text { Education }\end{array}$ & 3.14 & 0.39 & 3.12 & 2.06 & 3.82 & 1.000 \\
\hline & Department of School Teaching & 3.26 & 0.46 & 3.24 & 2.41 & 4.24 & 1.000 \\
\hline & $\begin{array}{l}\text { Department of Guidance and } \\
\text { Psychological Counseling }\end{array}$ & 3.31 & 0.48 & 3.29 & 1.82 & 4.35 & 1.000 \\
\hline & Department of History & 3.41 & 0.45 & 3.41 & 2.47 & 4.29 & 0.625 \\
\hline & $\begin{array}{l}\text { Department of Turkish Language } \\
\text { and Literature }\end{array}$ & 3.45 & 0.49 & 3.53 & 1.53 & 4.12 & 0.082 \\
\hline & $\begin{array}{l}\text { Department of Electrical and } \\
\text { Electronic Engineering }\end{array}$ & 3.20 & 0.51 & 3.24 & 1.53 & 4.12 & 1.000 \\
\hline & Faculty of Tourism & 3.22 & 0.46 & 3.24 & 2.41 & 4.12 & 1.000 \\
\hline & $\begin{array}{l}\text { Polatlir Social } \\
\text { Vocational School }\end{array}$ & 3.32 & 0.54 & 3.35 & 1.71 & 4.29 & 1.000 \\
\hline
\end{tabular}

According to the Kruskal Wallis test results, the Department of Physical Education and Sports Teaching students' Need for cognition average was not significantly different from the the other department students' Cognitive Need average ( $\mathrm{p}>0.05)$.

Table 3. A Comparison of Faith in intuition According to the Departments

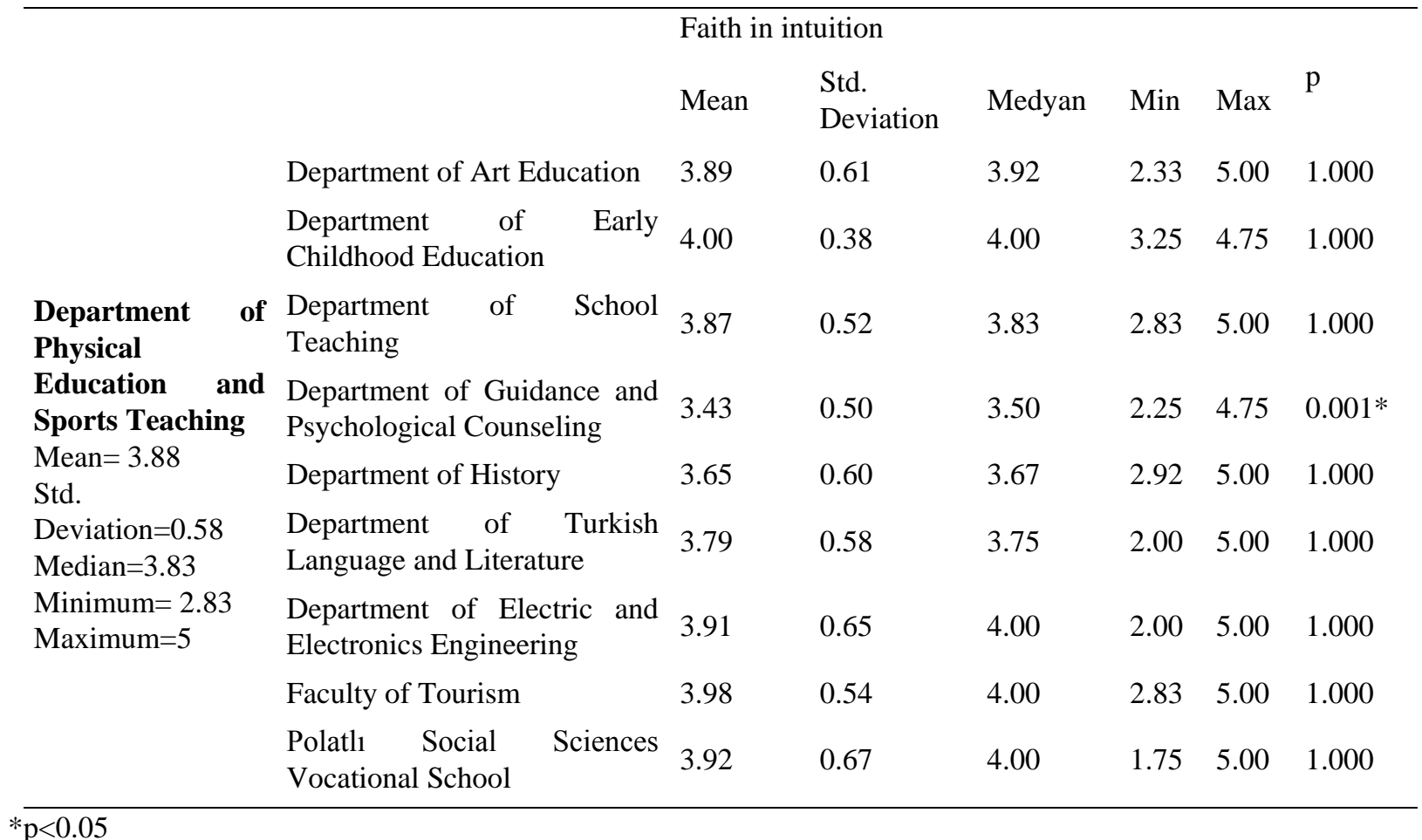

According to the Kruskal Wallis test results, the Department of Physical Education and Sports Teaching students' Faith in intuition was significantly higher than the Department of Guidance and Psychological Counseling students. 
Table 4. The Comparison of Happiness Levels and Rational-Experiential Thinking Styles According to Gender

\begin{tabular}{|c|c|c|c|c|c|c|c|c|}
\hline & & & Mean & $\begin{array}{l}\text { Std. } \\
\text { Deviation }\end{array}$ & Minimum & Maximum & Median & $\mathrm{p}$ \\
\hline \multirow{2}{*}{ Happiness } & & Male & 3.50 & 0.54 & 1.69 & 4.55 & 3.50 & \multirow{2}{*}{0.23} \\
\hline & & Female & 3.57 & 0.52 & 2.24 & 4.55 & 3.52 & \\
\hline \multirow{4}{*}{ 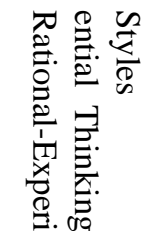 } & \multirow{2}{*}{$\begin{array}{l}\text { Need for } \\
\text { cognition }\end{array}$} & Male & 3.25 & 0.50 & 1.53 & 4.29 & 3.24 & \multirow{2}{*}{0.165} \\
\hline & & Female & 3.31 & 0.48 & 1.71 & 4.53 & 3.27 & \\
\hline & \multirow{2}{*}{$\begin{array}{l}\text { Faith in } \\
\text { intuition }\end{array}$} & Male & 3.80 & 0.56 & 2.00 & 5.00 & 3.83 & \multirow{2}{*}{$0.20^{\top}$} \\
\hline & & Female & 3.86 & 0.60 & 1.75 & 5.00 & 3.92 & \\
\hline
\end{tabular}

According to Mann Whitney U test results; happiness and thinking styles did not differ significantly by gender ( $p$ > 0.05). In other words, the levels of happiness and rational-experiential thinking styles of men and women can be said to be about equal.

Table 5. The Comparison of Happiness Levels and Rational-Experiential Thinking Styles According to Age Groups

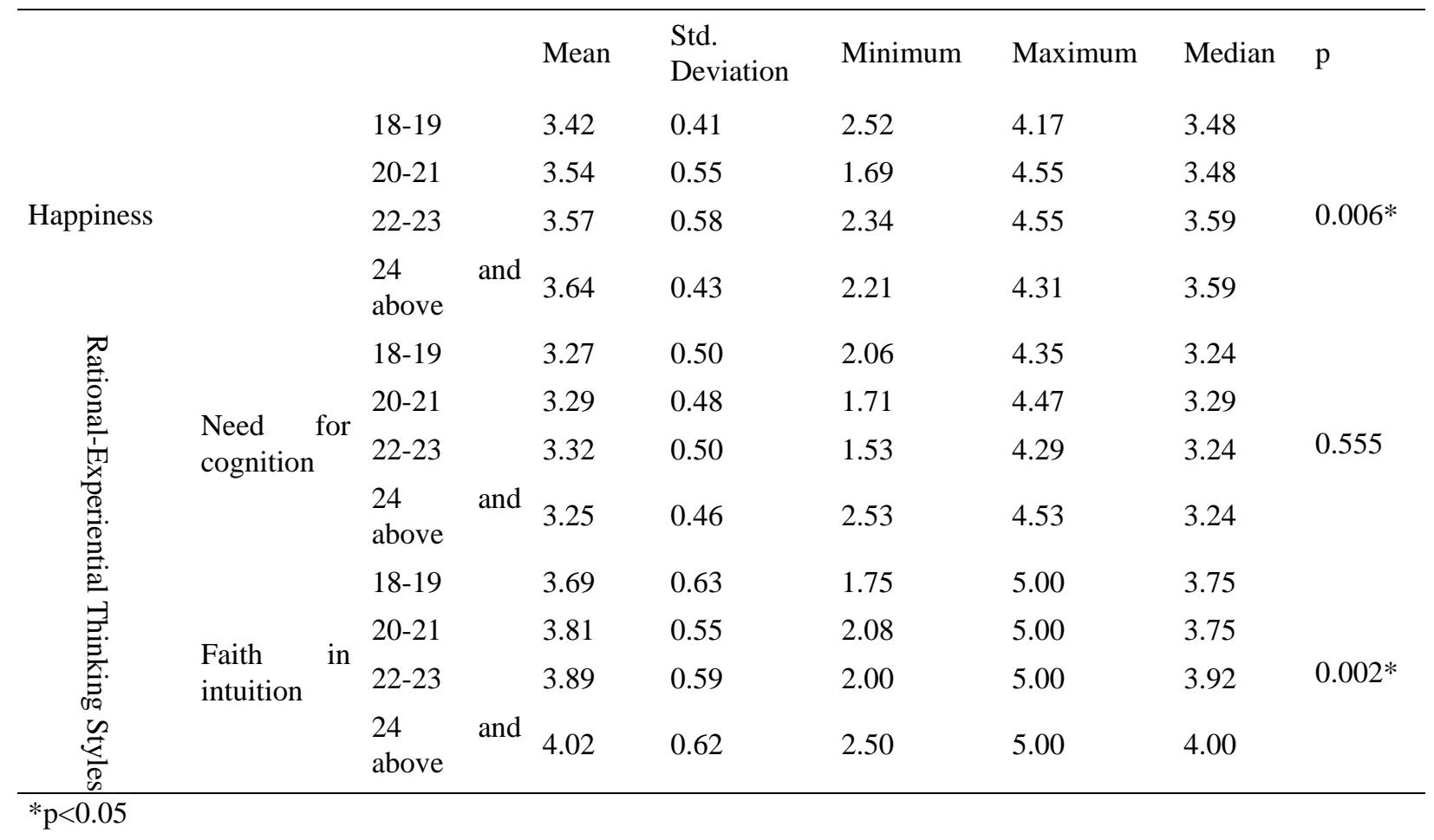

According to the Kruskal Wallis test results, while there was a significant difference between the happiness scale and faith in intuition according to the age groups $(\mathrm{p}<0.05)$, the need for cognition did not show any significant differences according to the age groups ( $>0.05$ ). For the Happiness scale, which varies significantly, the level of happiness of students in the 18-19 age group were significantly lower than the level of happiness in the age groups of 22-23 and 24 and above. The faith in intuition level of students in the 18-19 age group were significantly lower than the age group of $22-23$ and 24 and above. 
Table 6. The Relation between Happiness Scale and Rational-Experiential Thinking Styles

\begin{tabular}{|c|c|c|c|c|c|c|}
\hline & & & & Happiness & $\begin{array}{l}\text { Need for } \\
\text { cognition }\end{array}$ & $\begin{array}{l}\text { Faith in } \\
\text { intuition }\end{array}$ \\
\hline \multirow{6}{*}{$\begin{array}{l}\text { Spearman's } \\
\text { rho }\end{array}$} & \multirow[t]{2}{*}{ Happiness } & & $\mathrm{r}$ & \multirow{2}{*}{1} & -.026 & $.221^{* *}$ \\
\hline & & & $\mathrm{p}$ & & .506 & .000 \\
\hline & \multirow{2}{*}{$\begin{array}{l}\text { Need } \\
\text { cognition }\end{array}$} & \multirow[t]{2}{*}{ for } & $\mathrm{r}$ & -.026 & \multirow{2}{*}{1} & .065 \\
\hline & & & $\mathrm{p}$ & .506 & & .091 \\
\hline & \multirow{2}{*}{$\begin{array}{l}\text { Faith } \\
\text { intuition }\end{array}$} & \multirow[t]{2}{*}{ in } & $\mathrm{r}$ & $.221^{* *}$ & .065 & \multirow{2}{*}{1} \\
\hline & & & $\mathrm{p}$ & .000 & .091 & \\
\hline
\end{tabular}

According to the results of correlation analysis, there was a positive correlation between faith in intuition and happiness scale by $22.1 \%$. There was no significant relation between the happiness scale and need for cognition, nor the need for cognition and faith in intuition ( $p>0.05)$.

\section{Discussion, Conclusions, and Recommendations}

The Department of Physical Education and Sports Teaching students' average level of happiness was significantly higher than the Department of Guidance and Psychological Counseling, the Department of Turkish Language and Literature and the Polatlı Social Sciences Vocational School students. It is the level of physical activity that comes to mind when the reason for this difference is considered. It is known that physical education and sports teaching students have more physical activity in courses when we see the curriculum of the departments. Yet, this may not be indicated as the main reason, considering the possibility of exercising by students in other departments. This possibility will be equalized in terms of students in physical education and sports teaching as well as students in other departments when taking into account the possibility of extracurricular exercise of the physical education and sports teaching students. In light of this information when we investigate the relevant literature, an investigation (Huang \& Humphreys, 2012) about the relationship between participation in physical activity and the self-reported happiness in the United States shows that "both men and women gain happiness from participation..." Similarly, Stubbe, De Moor, Boomsma, and De Geus (2007) indicated that "exercise participation is associated with higher levels of life satisfaction and happiness..."

The Department of Physical Education and Sports Teaching students' need for cognition average was not significantly different from the other departments' students. However, the Physical Education and Sports Teaching students' Faith in intuition was significantly higher than the Department of Guidance and Psychological Counseling students. Happiness levels and thinking styles did not differ significantly by gender. In other words, the levels of happiness and the thinking styles of men and women can be said to be equal. Gender is a subject in the happiness studies. Although some studies about the happiness and gender state that there is no relation between them (Demir, 2017; Küsgülü, 2014; Zohour \& Fekri 2004), some findings claim that females are happier than males (Gülcan and Bal, 2014; Wood, Rhodes, \& Whelan, 1989) or males are happier than females (Akın \& Şentürk, 2012). While there was a significant difference between the Happiness and Faith in intuition scales according to the age groups, the need for cognitions did not show any significant difference according to the age groups. The level of happiness of the students in the 18-19 age group was significantly lower than the level of happiness in the age groups of 22-23 and 24 and above. According to Gülcan and Bal_(2014), there is a significant difference between age and happiness, whereas according to the result of Çakıroğlu (2007), age is not a significant variable for happiness in Turkey. The faith in intuition level of students in the 18-19 age group was significantly lower than the age group of 22-23 and 24 and above. Coşkuner, Gacar and Yanlıç (2012) evaluated the thinking styles of the Department of Physical Education and Sports Teaching undergraduate students in a study they did. In this direction, they found that the rational and intuitive thinking styles are moderate, and may vary depending on some variables. There was positive correlation between the Faith in intuition and Happiness scales (22.1\%). There was no significant relation between the happiness and need for cognition scales, nor the need for cognition and faith in intuition scales.

The following recommendations have been made based on the findings of this study: because of this study sample which one of the limitations of the study was not large, a study can be carried out on a larger sample. Moreover, future research can be done to compare the Physical Education and Teaching students with other departments' students through some different variables. In addition, different research methods can be employed to compare the students' happiness and thinking styles. 


\section{References}

Akın, H. B., \& Şentürk, E. (2012). Bireylerin mutluluk düzeylerinin ordinal lojistik regresyon analizi ile incelenmesi-analysing levels of happiness of individuals with ordinal logistic analysis. Öneri Dergisi, 10(37), 183-193.

Buluş, M. (2014). Reliability and Validity of Rational Experiential Thinking Styles Inventory. Ege Eğitim Dergisi, 3(1),. Retrieved from http://dergipark.gov.tr/egeefd/issue/4922/67341

Çakıroğlu, A. (2007). Relationship between quality of life and happiness in Turkey. Ortadoğu Teknik Üniversitesi, Sosyal Bilimler Enstitüsü, Ankara.

Carr, A. (2011). Positive psychology: The science of happiness and human strengths. Routledge.

Coşkuner, Z., Gacar, A., \& Yanlıç, N. (2012). Beden eğitimi ve spor öğretmen adaylarının düşünme stillerinin değerlendirilmesi. Spor ve Performans Araştırmalarl Dergisi,3(1). Retrieved from http://dergipark.ulakbim.gov.tr/omuspd/article/view/1009001568/1009001458

Csikszentmihalyi, M.,\& Hunter, J. (2003). Happiness in everyday life: The uses of experience sampling. Journal of happiness studies, 4(2), 185-199. https://doi.org/10.1023/A:1024409732742

Demir, R. (2017). Öğretmen adaylarının mutluluk, iyimserlik, yaşam anlamı ve yaşam doyumlarının incelenmesi. Unpublished master's thesis, Gaziantep University, EEducation Sciences Institution, Gaziantep.

Doğan, T., Sapmaz, F. ve Çötok Akıncı, N. (2012). Öz-eleştiri ve mutluluk. Katamonu Eğitim Dergisi, 21(1), 391-400.

Epstein, S., Pacini, R., Denes-Raj, V., \& Heier, H. (1996). Individual differences in intuitive-experiential and analytical-rational thinking styles. Journal of Personality and Social Psychology, 71(2), 390-405. http://dx.doi.org/10.1037/0022-3514.71.2.390

Grigorenko, E. L., \& Sternberg, R. J. (1995). Thinking styles. In International handbook of personality and intelligence, 205-229. Boston, MA: Springer. https://doi.org/10.1007/978-1-4757-5571-8_11

Gülcan, A., \& Bal, P. N. (2014). Genç yetişkinlerde iyimserliğin mutluluk ve yaşam doyumu üzerindeki etkisinin incelenmesi. Asian Journal of Instruction, 2(1), 41-52. Retrieved from http://dergipark.ulakbim.gov.tr/aji/article/view/1064000064

Heppner, P. P., Wampold, B. E., \& Kivlighan, D. M. (2007). Research design in counseling: Research, statistics, \& program evaluation. Cengage Learning.

Hills, P. \& Argyle, M. (2002). The Oxford Happiness Questionnaire: a compact scale for the measurement of psychological well-being. Personality and Individual Differences, 33(7), 1073-1082. https://doi.org/10.1016/S0191-8869(01)00213-6

Huang, H., \& Humphreys, B. R. (2012). Sports participation and happiness: Evidence from US microdata. Journal of Economic Psychology, 33(4), 776-793. https://doi.org/10.1016/j.joep.2012.02.007

İmamoğlu, S. (2008). Bilişsel-yaşantısal benlik teorisi ve yapılandırmacı düşünce. Marmara üniversitesi eğitim

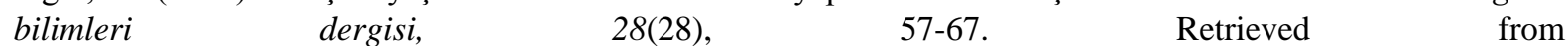
http://dspace.marmara.edu.tr/bitstream/handle/11424/1140/1676-3021-1-SM.pdf?sequence=1

Jacobsen, B. (2007). What is Happiness?. Existential Analysis: Journal of the Society for Existential Analysis, 18(1). Retrieved

from http://search.ebscohost.com/login.aspx?direct=true \&db=a9h\&AN=24478440\&lang=tr\&site=eds-live\&authtype $=$ ip, uid

Janssen, I., \& LeBlanc, A. G. (2010). Systematic review of the health benefits of physical activity and fitness in school-aged children and youth. International journal of behavioral nutrition and physical activity, 7(1), 40. https://doi.org/10.1186/1479-5868-7-40

Kaplan, Y., \& Çetinkaya, G. (2014). Spor yoluyla toplumsallaşma-yeniden toplumsallaşma süreci. International Journal of Science Culture and Sport, 2, 120-125. https://doi.org/10.14486/IJSCS183

Küsgülü, Ü. (2014). Üniversite ögrencilerinin mutluluk, umut ve narsisizm düzeylerinin incelenmesi. Unpublished Master's Thesis, Gaziosmanpaşa University, Education Sciences Institute, Tokat. 
Polit, D. F., \& Beck, C. T. (2010). Essentials of nursing research: Appraising evidence for nursing practice. Lippincott Williams \& Wilkins.

Rahman, S., Ansari, S. A., \& Parveen, F. (2016). Happiness as Correlates of Mental Well-Being. The International Journal of Indian Psychology, 3(3). Retrieved from http://oaji.net/articles/2016/1170-1463304733.pdf

Richards, J., Jiang, X., Kelly, P., Chau, J., Bauman, A., \& Ding, D. (2015). Don't worry, be happy: cross-sectional associations between physical activity and happiness in 15 European countries. BMC public health, 15(1), 53. https://doi.org/10.1186/s12889-015-1391-4

Rovai, A. P., Baker, J. D., \& Ponton, M. K. (2013). Social science research design and statistics: A practitioner's guide to research methods and IBM SPSS. Watertree Press LLC.

Schneider, F. W., Gruman, J. A., \& Coutts, L. M. (Eds.). (2011). Applied social psychology: Understanding and addressing social and practical problems. London: Sage.

Sternberg, R. J. (1988). Mental self-government: A theory of intellectual styles and their development. Human Development, 31, 197-224. https://doi.org/10.1159/000275810

Sternberg, R. J. (1999). Thinking styles. Cambridge: Cambridge University Press.

Sternberg, R.J. (2009). Düşünme stilleri (E. Güngör, Çev.). İstanbul: Sev.

Stubbe, J. H., De Moor, M. H. M., Boomsma, D. I., \& De Geus, E. J. C. (2007). The association between exercise participation and well-being: a co-twin study. Preventive medicine, 44(2), 148-152. https://doi.org/10.1016/j.ypmed.2006.09.002

Sundriyal, R., \& Kumar, R. (2014). Happiness and wellbeing. The International Journal of Indian Psychology, 1(4), 19-27. Retrieved from http://oaji.net/articles/2014/1170-1412083890.pdf

Warburton, D. E. R., Nicol, C. W., \& Bredin, S. S. D. (2006). Health benefits of physical activity: the evidence. CMAJ: Canadian Medical Association Journal, 174(6), 801-809. http://doi.org/10.1503/cmaj.051351

Wood, W., Rhodes, N., \& Whelan, M. (1989). Sex differences in positive well-being: A consideration of emotional style and marital status. Psychological Bulletin, 106(2), 249. https://doi.org/10.1037/0033-2909.106.2.249

Yetim A (2010). Sosyoloji ve Spor, Ankara: Berikan.

Zhang, L. F. (2000). Are thinking styles and personality types related?. Educational psychology, 20(3), 271-283. https://doi.org/10.1080/713663742

Zhang, L. F. (2001). Do styles of thinking matter among Hong Kong secondary school students?. Personality and Individual Differences, 31(3), 289-301. https://doi.org/10.1016/S0191-8869(00)00136-7

Zhang, L. F. (2002). Thinking styles and the big five personality traits. Educational psychology, 22(1), 17-31. https://doi.org/10.1080/01443410120101224

Zohour, A., \& Fekri, A. (2004). University students' hapiness at faculty of management and medical information sciences, Iran university of medical sciences, 1(31), 47-54. Retrieved from http://www.sid.ir/En/Journal/ViewPaper.aspx?ID=30782 